\title{
GENETIC DIVERSITY OF ISOLATES OF Colletotrichum spp. IN BANANA ${ }^{1}$
}

\author{
AMANDA LETÍCIA DA SILVEIRA ${ }^{2 *}$, MARIA GILMARA DE OLIVEIRA SOARES ${ }^{2}$, LUCAS SILVEIRA LOPES ${ }^{2}$, \\ JULIANA STRACIERI ${ }^{3}$, EDUARDO ALVES ${ }^{2}$
}

\begin{abstract}
Colletotrichum spp. is a pathogenic fungus of great importance in banana cultivation since it affects the fruit both in the field and in the post-harvest period, depreciating its commercial value. Although this disease is widely distributed in regions of banana cultivation, the different levels of aggression suggest the existence of genetic variability among Colletotrichum spp. isolates. The objective of the present study was therefore to verify the genetic diversity of Colletotrichum spp. in banana fruits presenting anthracnose symptoms using both molecular marker ISSR and morphological characterization. We obtained 30 isolates of the fungus from banana fruits from different states of Brazil and performed molecular characterization with five primers using the ISSR-PCR technique. The results were used to construct a dendrogram, relating the isolates according to their genetic proximity. The morphocultural characterization was performed by analyzing colony coloration and growth rate. These methods allowed us to reveal genetic and morphocultural variability among isolates.
\end{abstract}

Keywords: Variability. ISSR-PCR. Musa spp.

\section{DIVERSIDADE GENÉTICA DE ISOLADOS DE Colletotrichum spp. EM BANANA}

RESUMO - Colletotrichum spp. é um fungo patogênico de grande importância na cultura da bananeira uma vez que afeta o fruto tanto no campo quanto no período pós-colheita, depreciando seu valor comercial. Essa doença está amplamente distribuída nas regiões onde a bananeira é cultivada, entretanto há diferentes níveis de agressividade da mesma, sugerindo a existência de variabilidade genética entre isolados de Colletotrichum spp. Diante do exposto, o objetivo do presente estudo foi verificar a diversidade genética de isolados de Colletotrichum spp. associados a frutos de banana, apresentando sintomas de antracnose por meio de marcador molecular ISSR e caracterização morfológica. Foram utilizados 30 isolados do fungo, obtidos de frutos de bananeira de quatro Estados do país. A caracterização molecular foi feita pela técnica ISSR-PCR, utilizando cinco primers. Com os resultados obtidos, foi construído um dendrograma, relacionando os isolados de acordo com a sua proximidade genética. A caracterização morfocultural foi realizada por meio da avaliação da coloração da colônia e da velocidade de crescimento. Foi possível verificar a existência de variabilidade genética e morfocultural entre os isolados. Os marcadores ISSR foram eficientes na caracterização de isolados de Colletotrichum spp. associadas a frutos de bananeira.

Palavras-chave: Variabilidade. Caracterização molecular. Musa spp.

\footnotetext{
Reorrespanding aythor .

Paper extracted from the doctoral thesis of the first author.

${ }^{2}$ Department of Phytopathology, Universidade Federal de Lavras, Lavras, MG, Brazil; amandaagronomia@gmail.com - ORCID: 00000003-3248-9691, gilmaraagronomia@gmail.com - ORCID: 0000-0001-7580-8854, biolucassilveira@gmail.com - ORCID: 0000-00020906-9499, ealves@ufla.br-ORCID: 0000-0003-3185-9291.

${ }^{3}$ Department of Agricultural and Environmental Sciences, Universidade Federal de Santa Cruz, Ilhéus, BA, Brazil; juliana.uem@outlook.com - ORCID: 0000-0002-6772-9715.
} 


\section{INTRODUCTION}

Brazil is the fourth largest banana-producing country in the world, with a production of approximately 7 million tons in the 2018 crop (IBGE 2019), representing $6 \%$ of the worldwide total (FAO 2017). Banana production is distributed among the 27 units of the Federation, with the states of São Paulo and Minas Gerais being two of the largest producers.

Phytosanitary problems affect both the productivity of the crop and the export of its fruits. Several diseases can affect banana culture, a major one being anthracnose caused by the fungus Colletotrichum musae (Berk \& Curt). This infection can occur in the field, while the fruits are still green; however, the development of symptoms occurs in the maturation phase (CORDEIRO; MATOS, 2005).

There are currently no estimates of losses caused by anthracnose in banana cultivation. However, fruit stains and shelf life reduction undoubtedly result in losses for the producer, trader, and consumer (CORDEIRO; MATOS; FILHO 2004).

Anthracnose can be controlled by the application of fungicides, but this can be hampered when pathogens evolve resistance to various chemical products (McDONALD; LINDE, 2002).

The identification of Colletotrichum species based exclusively on their morphology and hosts was shown to be unreliable (THAUNG, 2008; PHOTITA et al., 2005). This is because several Colletrotrichum species may colonize a single host (MENEZES, 2006), and environmental factors may further complicate the species identification (PHOTITA et al., 2005). In addition, members of the species complex C. gloeosporioides (WEIR; JOHNSTON; DAMM, 2012) cannot be separated by morphology; therefore their correct identification requires phylogenetic analyses. Thus, the joint use of molecular techniques and morphological analyses increases the reliability of species identification (THAUNG, 2008). Correct identification of the pathogen is important for management planning and breeding programs aimed at plant resistance (MENEZES, 2006). Among the molecular techniques used, Inter-Simple Sequence Repeat Polymerase Chain Reaction (ISSR-PCR) has been highlighted for characterization and analysis of genotypic variability in Colletotrichum isolates (MEDEIROS et al., 2010; SANTOS et al., 2015; STRACIERI et al., 2015; SILVEIRA et al., 2016).

\section{MATERIAL AND METHODS}

\section{Collection of Colletotrichum spp. Isolates}

The Prata and Nanica commercial varieties of banana with typical symptoms of anthracnose were collected from the states of Minas Gerais (MG), São Paulo (SP), Santa Catarina (SC), and Rio Grande do Norte (RN) (Table 1). The fruits were washed and fragments (approximately $5 \mathrm{~mm}^{2}$ ) of the bark with disease symptoms were obtained. These fragments were surface disinfected and transferred to Petri dishes with PDA (potato-dextrose-agar) medium. The plates containing the fragments were maintained in BOD at $25 \pm 1{ }^{\circ} \mathrm{C}$ with a 12 hour photoperiod. After seven days, typical colonies of Colletotrichum spp. were evident. These were re-plated onto fresh PDA plates, and monosporic cultures were obtained. The thirty resulting isolates of Colletotrichum spp. were stored in PDA test tubes, coated with sterile mineral oil, and stored at room temperature.

\section{Pathogenicity test}

For the pathogenicity test, healthy cv. Nanica bananas were washed in running water, and disinfected with $2 \%$ sodium hypochlorite for 3 minutes. Next, holes were drilled in the fruits with multi-needles of $2 \mathrm{~mm}$ depth, and $20 \mu \mathrm{L}$ of conidial suspension containing $2 \times 10^{6}$ conidia/mL was added to each hole. The fruits were then wrapped with plastic bags and incubated at $25 \pm 2{ }^{\circ} \mathrm{C}$ with a relative humidity of $90 \pm 5 \%$ for 48 hours. The plastic bags were then removed and the fruits were incubated further until the development of lesions. The pathogenicity evaluation was performed by observing the presence of depressed and dark lesions that are characteristic of the disease. 
Table 1. Variety and provenance information of Colletotrichum spp. isolates (MG; Minas Gerais, SP; São Paulo, SC; Santa Catarina, RN; Rio Grande do Norte).

\begin{tabular}{|c|c|c|}
\hline Isolate & Variety & Source \\
\hline 1 & Nanica & Corupá - SC \\
\hline 2 & Nanica & $\operatorname{Arcos}-\mathrm{MG}$ \\
\hline 3 & Nanica & Arcos - MG \\
\hline 4 & Nanica & Registro - SP \\
\hline 5 & Prata & Januária - MG \\
\hline 6 & Prata & Pouso Alegre - MG \\
\hline 7 & Nanica & Ipanguaçu - RN \\
\hline 8 & Prata & Caldas - MG \\
\hline 9 & Prata & Passos - MG \\
\hline 10 & Prata & Caldas - MG \\
\hline 11 & Prata & Passos - MG \\
\hline 12 & Prata & Aparecida - SP \\
\hline 13 & Nanica & Registro - SP \\
\hline 14 & Nanica & Passos - MG \\
\hline 15 & Prata & Formiga - MG \\
\hline 16 & Prata & Tupaciguara - MG \\
\hline 17 & Prata & Registro - SP \\
\hline 18 & Nanica & Januária - MG \\
\hline 19 & Nanica & Passos - MG \\
\hline 20 & Nanica & Registro - SP \\
\hline 21 & Nanica & Jundiaí - SP \\
\hline 22 & Prata & Passos - MG \\
\hline 23 & Prata & Formiga - MG \\
\hline 24 & Prata & Pouso Alegre - MG \\
\hline 25 & Prata & Pouso Alegre - MG \\
\hline 26 & Nanica & $\operatorname{Arcos}-\mathrm{MG}$ \\
\hline 27 & Prata & Aiuruoca - MG \\
\hline 28 & Prata & Januária - MG \\
\hline 29 & Prata & Lavras - MG \\
\hline 30 & Prata & Lavras - MG \\
\hline
\end{tabular}

\section{Morphological characterization}

For the morphocultural analysis, colony discs $5 \mathrm{~mm}^{2}$ diameter were extracted from the margins of seven day-old monosporic cultures, cultured in BDA medium, and transferred to new plates containing the same culture medium. Thereafter, such cultures were incubated at $25{ }^{\circ} \mathrm{C}$ under continuous fluorescent light. Measurements of the diameter of the colonies were performed in orthogonal directions daily, until the colony of some isolates reached the edge of the plate. From the obtained data, the mycelial growth rate index (IVCM) was measured according to Nechet and Abreu (2002), using the formula described by Oliveira (1991):

$\mathrm{IVCM}=\sum(\mathrm{D}-\mathrm{Da})$

IVCM: mycelial growth rate index $\left(\mathrm{cm} \mathrm{day}^{-1}\right)$; D: current average diameter $(\mathrm{cm})$;
Da: average diameter of the previous day (cm);

$\mathrm{N}$ : number of days after inoculation.

\section{DNA extraction and PCR-ISSR reactions}

DNA extraction from the isolates was performed according to the protocol of KuramaeIzioka (1997), and evaluation of the quantity and the quality of the DNA was performed using a NanoDrop spectrophotometer and agarose gel electrophoresis. PCR reactions were performed using the following reagent quantities: $5 \mu \mathrm{L}$ GoTaq ${ }^{\circledR}$ Colorless Master Mix, 5 pmol primer, 60 ng DNA and sterile pure water to a total volume of $20 \mu \mathrm{L}$. Five ISSR primers were chosen based on previous studies on species belonging to the genus Colletotrichum (Table 2). 
Table 2. Primer sequences and annealing temperatures.

\begin{tabular}{ccc}
\hline Primers & Sequence $\left(5^{\prime}-3^{\prime}\right)$ & Ring Temperature \\
PC2 & GACAGACAGACAGACA & $45.1^{\circ} \mathrm{C}$ \\
AF80820 & AGAGAGAGAGAGAGAGT & $42.5^{\circ} \mathrm{C}$ \\
AF80822 & GAGAGAGAGAGAGAGAT & $42.9^{\circ} \mathrm{C}$ \\
AF80821 & AGAGAGAGAGAGAGAC & $46.8^{\circ} \mathrm{C}$ \\
PC1 & GTGGTGGTGGTGGTG & $57.2^{\circ} \mathrm{C}$ \\
\hline
\end{tabular}

PCR-ISSR reactions were performed in an AmpliTherm thermocycler using the following conditions: 1 cycle at $95{ }^{\circ} \mathrm{C}$ for 3 minutes, then 35 cycles of; $94{ }^{\circ} \mathrm{C}$ for 40 seconds, annealing for 40 seconds (see Table 2 for primer-specific temperatures), and $72{ }^{\circ} \mathrm{C}$ for 1 minute; then a final incubation at $72^{\circ} \mathrm{C}$ for 10 minutes. The PCR products were subject to electrophoresis in $1 \mathrm{X}$ TEB buffer $(89 \mathrm{mM}$ Tris, $89 \mathrm{mM}$ boric acid, $2.5 \mathrm{mM}$ EDTA, $\mathrm{pH} 8.3$ ) using a $1.0 \%$ agarose gel containing $2 \mu \mathrm{L}$ of GelRed ${ }^{\circledR}$ (Invitrogen), and visualized under UV light on MiniBIS Pro photodocumentation equipment (DNR Bio-Imaging Systems). Molecular Marker $1 \mathrm{~kb}$ DNA (BioLabs $\left.{ }^{\circledR}\right)$ was used as the molecular size standard.

\section{Analysis and construction of the dendrogram}

The images of the gels containing the PCRISSR reaction products were analyzed manually, and a binary matrix was created, with 1 signifying band presence, and 0 signifying band absence. This binary matrix was converted into a distance matrix with XLSTAT software (Addinsoft $\AA$, version 2014), using the Jaccard coefficient. To visualize and analyze the genetic relationships between isolates, a dendrogram was then constructed using the Distance and UPGMA algorithm ("Unweighted Pair Group Method Using Arithmetic Average").

\section{RESULTS AND DISCUSSION}

\section{Pathogenicity test}

All the isolates displayed evidence of pathogenicity in the inoculated fruits. Depressed dark lesions were observed, delimiting the inoculation points on the external surface of the fruits. The control (inoculated only with distilled water) did not present the appearance of lesions.

\section{Morphocultural characterization}

It was possible to separate the 30 isolates into 9 groups with respect to the colony coloration following evaluation of the front and back of the plates, allowing creation of a scale of coloration notes (Table 3 and Figure 1). There was variation between the colonies, but the color of the front and back of the plates were the same in all plates evaluated.

Table 3. Coloration classification groups for Colletotrichum spp. in potato dextrose agar medium.

\begin{tabular}{ccc}
\hline Scale & Petri dish front & Coloring of Colonies \\
\hline 1 & White & White \\
2 & Grayish white with dark scoring & Grayish white with dark scoring \\
3 & Grayish white with salmon and dark scores & Grayish white with salmon and dark scores \\
4 & White with dark scoring & White with dark scoring \\
5 & Salmon with salmon scores & Salmon with salmon scores \\
6 & Salmon with salmon and dark scores & Salmon with salmon and dark scores \\
7 & White with salmon and dark scores & White with salmon and dark scores \\
9 & White to salmon with dark scoring & White to salmon with dark scoring \\
\hline
\end{tabular}




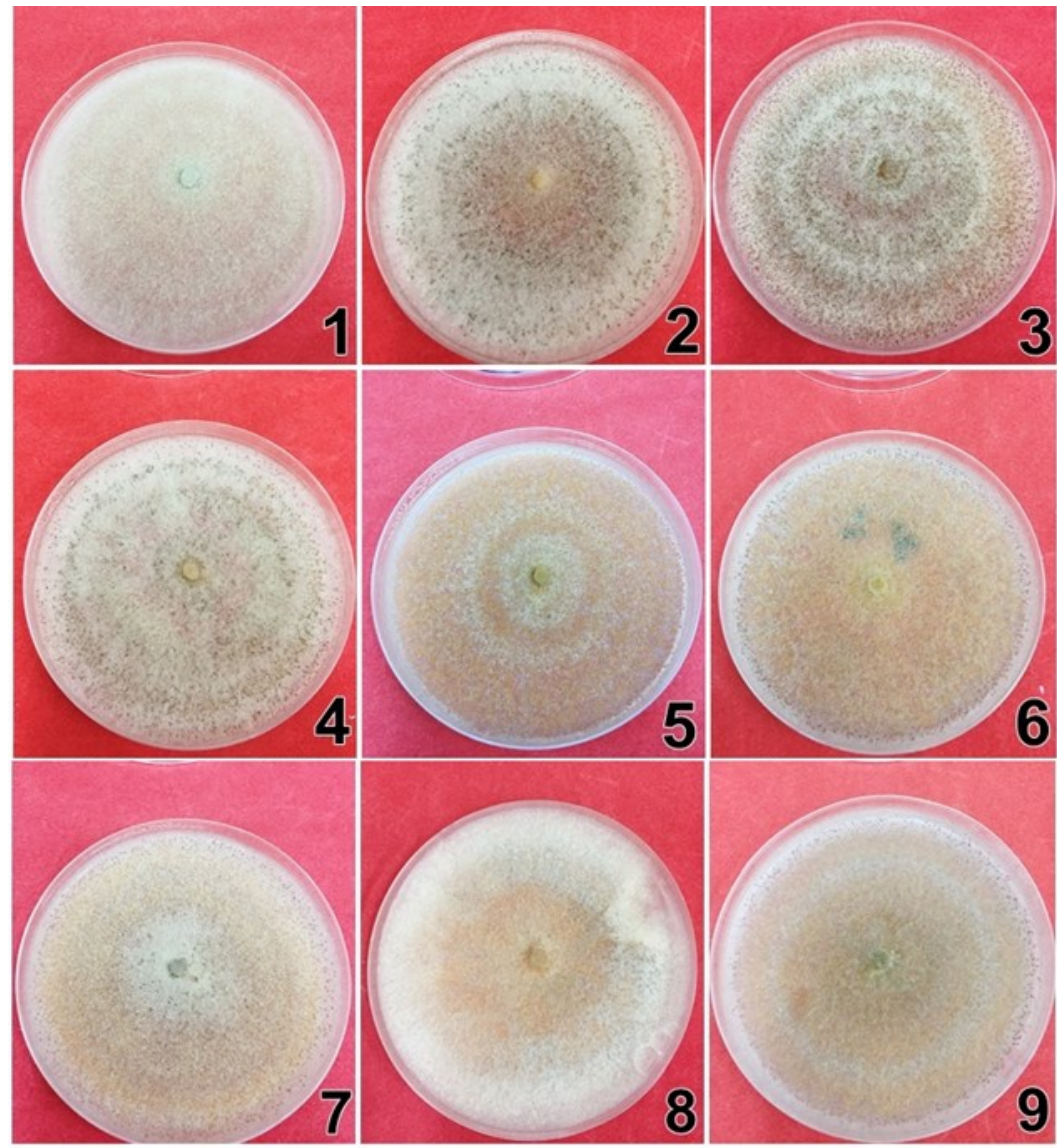

Figure 1. Examples of the coloration classification groups of Colletotrichum spp. Isolates.

Subtitle: 1: White; 2: Grayish white with dark scoring; 3: Grayish white with salmon and dark scores; 4: White with dark scoring; 5: Salmon with salmon scores; 6: Salmon with salmon and dark scores; 7: White with salmon and dark scores; 8: White to salmon with dark scoring; 9: White salmon with salmon and dark scores.

Approximately $36 \%$ of the isolates had colonies of white salmon color, with a thin aerial topography and presence of orange conidial masses, corresponding to coloration group 8 (Table 3 ). The presence of mycelial sectors was only observed in two isolates (6.6\%); numbers 29 and 22. The emergence of sectors was independent of the collection area or variety. The colony coloration pattern observed in this study is similar to that observed by Photita et al. (2005), who verified the formation of thin aerial mycelium with white to light gray coloring and intense conidial masses in pathogenic isolates of C. musae.

Similarly, Santos et al. (2015) separated 30 isolates from Pernambuco into 3 staining groups; white, cream, and salmon, and indicated the presence of aerial mycelium. Couto and Menezes (2004) observed the formation of white, gray, dark gray, and rosy gray colonies in isolates of $C$. musae from six regions of the State of Pernambuco, with the front and reverse coloration being identical. The great variation of coloration found in these and other works of the literature can be explained by the high genetic variability in Colletotrichum spp.

Table 4 shows data on the mycelial growth rate (IVCM) in PDA medium, colony coloration, and pathogenicity of the isolates. There were significant differences as assessed by the Scott-Knott test (P $<0.05$ ) for the IVCM of the isolates during five days of evaluation. All isolates had an average growth of more than $1.0 \mathrm{~cm} \mathrm{day}^{-1}$. The highest IVCM $(2,493$ $\mathrm{cm} \mathrm{day}^{-1}$ ) was observed in isolate 29 , whereas the lowest growth rate $\left(1,426 \mathrm{~cm} \mathrm{day}^{-1}\right)$ was observed in isolate 16. It is assumed that IVCM may be related to the development of the disease in the field, with higher IVCM implying a greater aggressiveness of the disease. However, to confirm this correlation, assessments of disease severity and speed of lesion development in fruits would be necessary. 
Table 4. Classification of Colletotrichum spp. isolates from the banana tree, showing mycelial growth rate index (IVCM), colony color (CC), absence or presence of sectors (S), and pathogenicity (P).

\begin{tabular}{|c|c|c|c|c|}
\hline Isolates & IVCM* & $\mathrm{CC}$ & $\mathrm{S}$ & $\mathrm{P}$ \\
\hline 1 & $2.053 \mathrm{c}$ & 5 & - & + \\
\hline 2 & $1.990 \mathrm{c}$ & 7 & - & + \\
\hline 3 & $1.790 \mathrm{~b}$ & 2 & - & + \\
\hline 4 & $1.763 b$ & 8 & - & + \\
\hline 5 & $1.756 \mathrm{~b}$ & 8 & - & + \\
\hline 6 & $2.030 \mathrm{c}$ & 1 & - & + \\
\hline 7 & $1.960 \mathrm{c}$ & 8 & - & + \\
\hline 8 & $2.023 \mathrm{c}$ & 7 & - & + \\
\hline 9 & $2.110 \mathrm{c}$ & 4 & - & + \\
\hline 10 & $1.936 \mathrm{c}$ & 8 & - & + \\
\hline 11 & $1.946 \mathrm{c}$ & 8 & - & + \\
\hline 12 & $2.036 \mathrm{c}$ & 8 & - & + \\
\hline 13 & $1.453 \mathrm{a}$ & 9 & - & + \\
\hline 14 & $2.420 \mathrm{~d}$ & 7 & - & + \\
\hline 15 & $1.940 \mathrm{c}$ & 2 & - & + \\
\hline 16 & $1.426 \mathrm{a}$ & 8 & - & + \\
\hline 17 & $1.856 \mathrm{~b}$ & 9 & - & + \\
\hline 18 & $2.410 \mathrm{~d}$ & 6 & - & + \\
\hline 19 & $2.210 \mathrm{~d}$ & 3 & - & + \\
\hline 20 & $1.693 \mathrm{~b}$ & 8 & - & + \\
\hline 21 & $1.953 \mathrm{c}$ & 1 & - & + \\
\hline 22 & $2.016 \mathrm{c}$ & 7 & + & + \\
\hline 23 & $1.970 \mathrm{c}$ & 8 & - & + \\
\hline 24 & $2.266 \mathrm{~d}$ & 8 & - & + \\
\hline 25 & $2.080 \mathrm{c}$ & 2 & - & + \\
\hline 26 & $2.000 \mathrm{c}$ & 7 & - & + \\
\hline 27 & $1.626 \mathrm{~b}$ & 8 & - & + \\
\hline 28 & $2.393 \mathrm{~d}$ & 7 & - & + \\
\hline 29 & $2.493 \mathrm{~d}$ & 7 & + & + \\
\hline 30 & $2.070 \mathrm{c}$ & 7 & - & + \\
\hline
\end{tabular}

*Means followed by the same letter belong to the same group by the Scott-Knott test at the $5 \%$ probability level.

\section{ISSR analysis}

Polymorphism was observed among the isolates by molecular analysis using ISSR primers. The five ISSR primers chosen allowed DNA amplification of all isolates, producing a total of 34 polymorphic bands (TableE 5).
Different fragments, with band sizes ranging from 500 to $3000 \mathrm{bp}$, were generated with the five ISSR primers used. The primer PC2 resulted in the greatest number of amplified bands, whereas AF80820 produced the lowest number of amplified bands (Table 5).

Table 5. ISSR primers used and number of polymorphic bands generated.

\begin{tabular}{cc}
\hline Primers & Number of Bands \\
\hline PC2 & 9 \\
AF80820 & 4 \\
AF80822 & 7 \\
AF80821 & 7 \\
PC1 & 7 \\
\hline
\end{tabular}

Analysis of the band pattern generated by each of the five primers allowed production of a binary matrix and, subsequently, a distance matrix, which was used in the construction of a dendrogram (Figure 2).

The mean similarity observed in this study was 0.795; the largest (1.00) being found between isolates 5 and 24 of Pouso Alegre (MG), and between isolates 14 and 22 of Passos (MG). The lowest similarity (0.586) was observed between isolates 1 from Corupá (SC) and 25 from Pouso
Alegre (MG).

In the dendrogram analysis, the isolates were divided into 4 distinct groups. The first group contained only isolate 1 from the city Corupá, in Santa Catarina. The second group contained 25 isolates (83\%); 18 from Minas Gerais $(2,3,5,6,8$, $9,10,11,14,15,16,18,19,22,23,24,26$, and 27), 6 from São Paulo (4, 12, 13, 17, 20, and 21), and 1 from Ipanguaçu in Rio Grande do Norte (7). The third group contained only isolate 25 from the city of Pouso Alegre in Minas Gerais, and the fourth group 
contained 3 isolates from the State of Minas Gerais $(28,29,30)$.

Among the four groups formed, it is worth noting that group I (composed only of isolate 1, originating in Corupá - SC) displayed the greatest genetic distance from other isolates, suggesting that isolate 1 has characteristics differentiating it from the others. It is also worth noting that this was the only isolate belonging to coloration group 5 . The genetic distance and morphological difference between this isolate and the others may be due to the relative geographical distance of the origins of the isolates.

\section{Dendrogram}

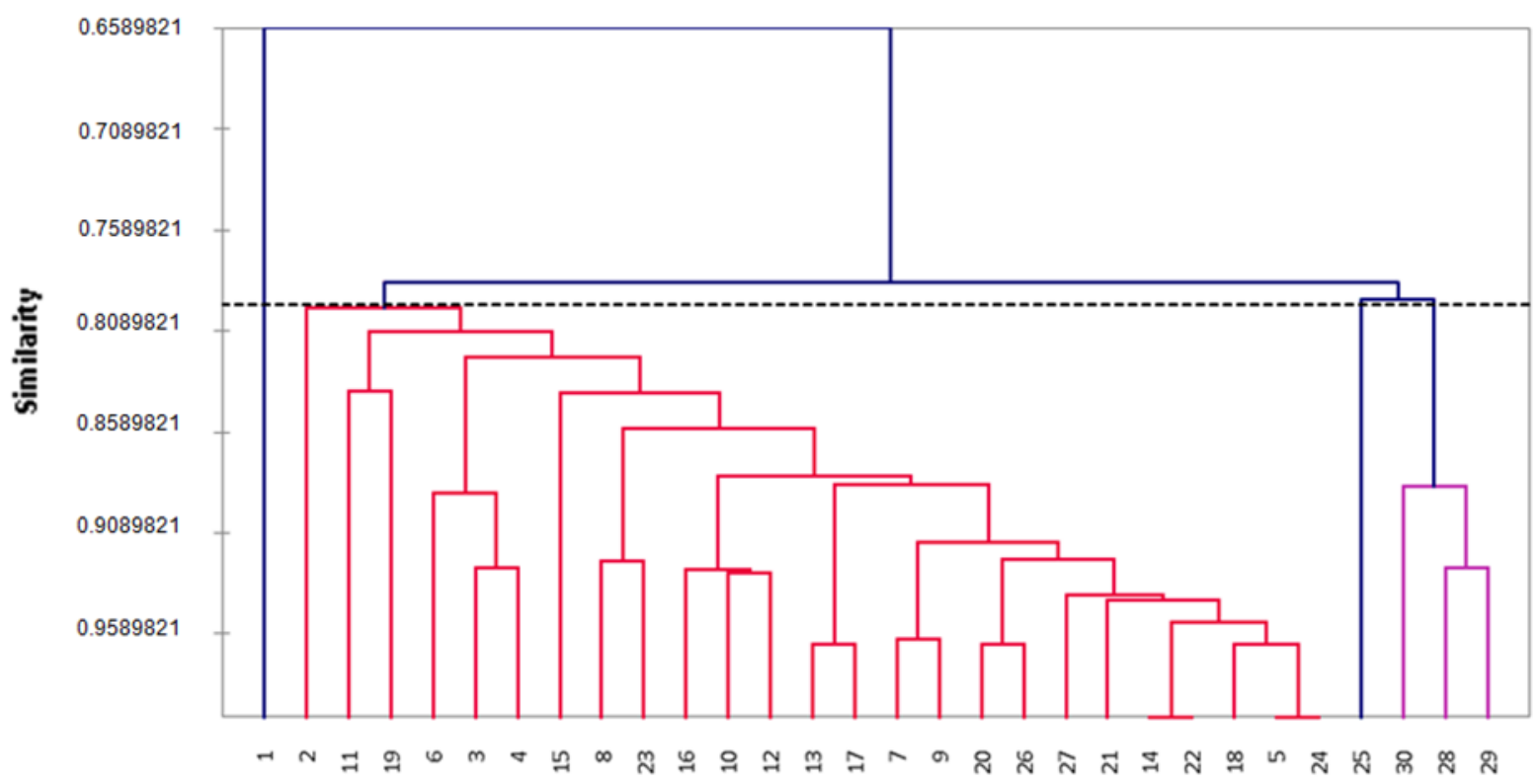

Figure 2. Dendrogram generated by the UPGMA method, showing genetic similarity of 30 isolates of Colletotrichum spp. by the Jaccard coefficient.

The same cannot be observed in group II, which was composed of isolates originating from MG, SP and RN. Genetic diversity occurred within this group even among isolates from the same city, and it was not possible to relate the place of origin to genetic similarities. Colony coloration and mean IVCM also varied among isolates from the same city. The existence of diversity among isolates from the same site further reinforces the high variability in Colletotrichum spp.

Similar results were obtained by Souza et al. (2013) who could not relate the place of origin to genetic diversity in the characterization of $C$. gloeosporioides of mango, as well as DenoyesRothan et al. (2013), who showed similar results for C. gloeosporioides and C. acutatum of strawberry.

Group III was composed of isolate 25, from Pouso Alegre - MG, and group IV was composed of three isolates from MG; 28, 29 and 30. The fact that these isolates were not grouped with the other isolates from $\mathrm{MG}$ indicates that they have some genetic differences in relation to the others. However, the isolates of group III and IV showed similar coloration to the other isolates from $\mathrm{MG}$, with isolate 25 belonging to coloration group 2 and isolates 28,29 , and 30 to group 7 .

The results obtained in this study suggest that there is not always a correlation between molecular and morphological data, since the isolates that have the same coloration or similar average IVCM are not always in the same group in the molecular analysis. As previously reported in the literature, this information reinforces the need for the joint use of molecular techniques and morphological analyses to increase the reliability of species characterization (THAUNG, 2008; PHOTITA et al., 2005; MENEZES, 2006).

\section{CONCLUSIONS}

The morphocultural characterization was not able to identify variability among the isolates of Colletotrichum spp.

ISSR markers are efficient in demonstrating the genetic variability of Colletotrichum isolates and discriminating the presence of different species, but they are not able to determine the species, for which phylogenetic analyses would be necessary.

Although there is genetic diversity among isolates of Colletotrichum spp., there is no relationship between the isolates and their place of origin, nor the varieties used.

\section{REFERENCES}

CORDEIRO, Z. J. M.; MATOS, A. P.; FILHO, P. E. M. Doenças e Métodos de Controle. In:. BORGES, 
A. L.; SOUZA, L. S. O cultivo da bananeira. Cruz das Almas: Embrapa Mandioca e Fruticultura, 2004. cap. 9 , p. 146-182.

CORDEIRO, Z. J. M.; MATOS, A. P. Doenças da banana. Informe Agropecuário, v. 26, n. 228, p. 12 $16,2005$.

COUTO, E. F.; MENEZES, M. Caracterização fisiomorfológica de isolados de Colletotrichum musae. Fitopatologia Brasileira, v. 29, n. 4, p. 406412, 2004.

DENOYES-ROTHAN, B. et al. Genetic diversity and pathogenic variability among isolates of Colletotrichum species from strawberry. Phytopathology, v. 93, n. 2, p. 219-228, 2003.

FOOD AND AGRICULTURE ORGANIZATION OF THE UNITED ORGANIZATIONS - FAO . Production Crops Primary. Disponível em: $<$ http:// www.fao.org > Acesso em: 01 set. 2017.

INSTITUTO BRASILEIRO DE GEOGRAFIA E ESTATÍSTICA - IBGE. Levantamento Sistemático da Produção Agrícola - LSPA. Disponível em: $<$ https://sidra.ibge.gov.br> Acesso em: 10 abr. 2019.

KURAMAE-IZIOKA, E. E. A rapid, easy and high yield protocol for total genomic DNA isolation of Colletotrichum gloeosporioides and Fusarium oxysporum. Revista Unimar, v. 19, n. 3, p. 683-689, 1997.

MCDONALD, B. A.; LINDE, C. Pathogen population genetics, evolutionary potential, and durable resistance. Annual review of phytopathology, v. 40, n. 1, p. 349-379, 2002.

MEDEIROS, L. V. et al. pelB gene in isolates of Colletotrichum gloeosporioides from several hosts. Genetic Molecular Research, v. 9, n. 2, p. 661-673, 2010 .

MENEZES, M. Aspectos biológicos e taxonômicos de espécies do gênero Colletotrichum. Anais da Academia Pernambucana de Ciência Agronômica, v. 3, n. 1, p. 170-179, 2006.

NECHET, K. L.; ABREU, M. S. Caracterização morfológica e testes de patogenicidade de isolados de Colletotrichum sp. obtidos de cafeeiro. Ciência e Agrotecnologia, v. 26, n. 6, p. 1135-1142, 2002.

OLIVEIRA, J. A. Efeito do tratamento fungicida em sementes no controle de tombamento de plântulas de pepino (Cucumis sativus L.) e pimentão (Capsicum annum L.).1991. 111 f.
Dissertação (Mestrado em Agronomia) Universidade Federal de Lavras, UFLA, Lavras, 1991.

PHOTITA, W. et al. Morphological and molecular characterization of Colletotrichum species from herbaceous plants in Thailand. Fungal Diversity, v. 39, n. 17, p. 117-133, 2005.

SANTOS, P. C. M. et al. Diversity of genotypic and pathogenic ff Colletotrichum musae In Pernambuco. Revista Brasileira de Fruticultura, v. 37, n. 2, p. 355-366, 2015.

SILVEIRA, A. L. et al. Caracterização molecular de isolados de Colletotrichum spp. associados a podridão floral dos citros. Revista Brasileira de Fruticultura, v. 38, n. 1, p. 64-71, 2016.

SOUZA, A. et al. Lack of host specificity of Colletotrichum spp. isolates associated with anthracnose symptoms on mango in Brazil. Plant Pathology, v. 62, n. 1, p. 1038-1047, 2013.

STRACIERI, J. Caracterização morfocultural e molecular de Colletotrichum spp. associados a antracnose em manga, mamão e goiaba. 2015. 109 f. Tese (Doutorado em Agronomia: Área de Concentração em Produção Vegetal) - Universidade Estadual Paulista Júlio de Mesquita Filho, UNESP, Jaboticabal, 2015

THAUNG, M. M. Coelomycete systematics with special reference to Colletotrichum. Mycoscience, v. 49, n. 6, p. 373-378, 2008.

WEIR, B. S.; JOHNSTON, P. R.; DAMM, U. The Colletotrichum gloeosporioides species complex. Studies in Mycology, v. 73, n. 1, p. 115-180, 2012. 